\title{
Technical and Economic Analysis on Masonry Materials of Exterior Walls for Building Energy Conservation
}

\author{
Yanhong Wang*, Yonghe Yao, Yuping Wu, Xiaozhen Li \\ Jinhua polytechnic, Jinhua 321007, China
}

Corresponding Author Email: yyh527@163.com

https://doi.org/10.18280/rcma.290302

Received: 2 April 2019

Accepted: 1 June 2019

\section{Keywords:}

energy conservation, building envelope, masonry material, technical and economic analysis, ceramsite aerated concrete (CAC) blocks

\section{INTRODUCTION}

With the gradual depletion of non-renewable energy resources, the energy issue has become a bottleneck of future development. Therefore, many countries are increasingly aware of the importance of energy conservation [1]. Statistics show that roughly $1 / 3$ of world's energy is consumed by buildings. The building energy consumption mainly occurs as heat is dissipated via the exterior walls of building envelope and energy is consumed by the heating and cooling system [2]. In a building, $27.5 \%$ of heat loss takes place at the exterior walls, while only $18.9 \%$ happens at exterior windows and $7.9 \%$ occurs on the roof. This means the exterior walls should be the focus to reduce building energy consumption [3-4].

According to the relevant literature, most countries are reducing building energy consumption from two aspects: enhancing the heat insulation of building envelope and improving the efficiency of heating and cooling system [5-6]. In China, the heat transfer coefficient (HTC) of building envelope is regarded as a key index for building energy conservation. The HTC of exterior walls must fall within $1.0 \sim 1.55 \mathrm{~W} /\left(\mathrm{m}^{2} \cdot \mathrm{K}\right)$ in hot summer and cold winter regions, only $1 / 4 \sim 1 / 2$ of that in places on similar latitudes in Northern Europe. Thus, it is of great significance to improve the heat insulation of exterior walls in China [7].

There are many software suites for energy-efficient design (e.g. DOE-2, EnergyPlus and PKPM) and cost analysis (e.g. STAT and GBQ) [8-9]. However, there is no comprehensive technical and economic analysis on the energy efficiency of exterior walls or their masonry materials. To make up for this gap, this paper selects suitable energy efficient design software and cost analysis software, and relies on them to analyze the energy efficiency of exterior walls and their masonry materials from technical and economic perspectives. In this way, the optimal masonry material was identified for exterior walls, making a great contribution to the energy conservation of buildings.

\section{TYPES AND PROPERTIES OF MASONRY MATERIALS}

Currently, there are three types of masonry materials for the exterior walls of energy-efficient buildings: sintered porous bricks (SPBs), autoclaved aerated concrete (AAC) blocks and ceramsite aerated concrete (CAC) blocks [10-12]. The SPBs are produced by roasting clay, shale, coal gangue, fly ash, sludge and other solid wastes [13]. The AAC blocks are made of cement, lime, slag, sand and fly ash through mixing, pouring, foaming, autoclaving and cutting [14]. The preparation of CAC blocks is relatively complicated: the cementing materials (i.e. cement and fly ash) are mixed into a slurry with foaming agent and water; next, light ceramistes, whose volume ratio is equal to or greater than $40 \%$, are added into the slurry and stirred mechanically; the stirred mixture is then subjected to pouring, vibration, steam curing and cutting [15]. The technical properties of the three masonry materials are compared in Table 1 below.

The comparison shows that the CAC blocks are more suitable than the SPBs and the AAC blocks for exterior walls of buildings, thanks to their excellent technical properties, such as lightweight, high strength, ultralow shrinkage, strong impermeability, high self-insulation, sound insulation, high dimensional accuracy, good appearance, simple process, fast bricklaying and the elimination of the need for waterproof or crack-resistant layers [16]. 
Table 1. Technical properties of the three masonry materials [17-19]

\begin{tabular}{|c|c|c|c|}
\hline \multirow{2}{*}{ Indices } & \multicolumn{3}{|c|}{ Types of masonry materials } \\
\hline & SPBs & AAC blocks & CAC blocks \\
\hline $\begin{array}{l}\text { Dry density } \\
\mathrm{kg} / \mathrm{m}^{3}\end{array}$ & $\begin{array}{c}\text { About 1,500; heavy deadload; } \\
\text { high steel consumption in } \\
\text { foundation and structure }\end{array}$ & $\begin{array}{c}\text { About 750; light deadload; low } \\
\text { steel consumption in foundation } \\
\text { and structure }\end{array}$ & $\begin{array}{l}\text { About } 750 \text {; light deadload; low steel } \\
\text { consumption in foundation and structure }\end{array}$ \\
\hline $\begin{array}{l}\text { Thermal conductivity } \\
\mathrm{W} /\left(\mathrm{m}^{2} \cdot \mathrm{K}\right)\end{array}$ & $\leq 0.58$; no self-insulation & $\leq 0.18$; self-insulation & $\leq 0.18$; self-insulation \\
\hline $\begin{array}{l}\text { Strength } \\
\mathrm{MPa}\end{array}$ & $\geq 10$; high strength & $\geq 3.5$; low strength & $\geq 5.0 ;$ moderate strength \\
\hline $\begin{array}{c}\text { Water absorption } \\
\%\end{array}$ & 30-40; low impermeability & 50-60; no impermeability & 15-20; strong impermeability \\
\hline $\begin{array}{l}\text { Dry shrinkage } \\
\mathrm{mm} / \mathrm{m}\end{array}$ & $\begin{array}{l}\text { About } 0.3 \text {; not prone to } \\
\text { shrinkage crack }\end{array}$ & About 0.8 ; prone to shrinkage crack & About 0.2 ; no shrinkage crack \\
\hline Sound insulation & Poor sound insulation & General sound insulation & Sound insulation and absorption \\
\hline Workability & $\begin{array}{l}\text { Small single block, slow } \\
\text { bricklaying }\end{array}$ & $\begin{array}{c}\text { Complex process, requiring } \\
\text { waterproof and crack-resistant } \\
\text { layers }\end{array}$ & $\begin{array}{c}\text { Large single block, simple process, fast } \\
\text { bricklayer, requiring no waterproof or } \\
\text { crack-resistant layers }\end{array}$ \\
\hline
\end{tabular}

\section{TECHNICAL AND ECONOMIC ANALYSIS}

\subsection{Energy-efficient design analysis}

The most popular energy-efficient design software, PKPM, was selected to analyze the energy efficiency of the masonry materials for exterior walls. In the light of the relevant codes and engineering building parameters [8], three envelope models were set up based on the exterior walls made of the SPBs, the AAC blocks and the CAC blocks, respectively. The software modules were executed according to the following sequence: File management, Open project, Envelope energy, Material editing, Index calculation, Weighting and Export report. The structural layers were adjusted continuously to achieve the required energy-efficiency indices of walls and the optimal structural effect with the fewest exterior insulation layers, the thinnest material and the simplest construction process.

\subsection{Cost analysis}

Based on the relevant data determined in PKPM energyefficient design, the GBQ software [9], the most widely used building cost analysis software in China, was employed to compute the cost of exterior walls made of the SPBs, the AAC blocks and the CAC blocks, respectively. The software modules were executed according to the following sequence: New project, New section, Project management, New unit work, Project overview, List and bid price, Measures, Other items, $3 \mathrm{M}$ (manpower, materials and machines) summary, cost summary, and export report.

\section{PROJECT APPLICATION}

\subsection{Project overview}

The SPBs, the AAC blocks and the CAC blocks were separately used to build the exterior walls of a residential building in Jinhua, eastern China's Zhejiang province. The project site (E: $119^{\circ} 65^{\prime} ; \mathrm{N}: 29^{\circ} 12^{\prime}$ ) belongs to the subtropical monsoon climate. The $23.20 \mathrm{~m}$-tall building covers an area of $2,348.90 \mathrm{~m}^{2}$. There are eight floors above ground and a basement floor. The total volume of the building is $9,178.36 \mathrm{~m}^{3}$, of which $6,811.81 \mathrm{~m}^{3}$ is aboveground. The surface area of the building is $2,994.13 \mathrm{~m}^{2}$. With a shear wall structure, the building has a shape coefficient of 0.44 . In the building envelope, the exterior walls (excluding windows) cover an area of $1,010.638 \mathrm{~m}^{2}$, the thermal bridge columns $695.130 \mathrm{~m}^{2}$, the thermal bridge beams $267.540 \mathrm{~m}^{2}$ and the thermal bridge floors $67.920 \mathrm{~m}^{2}$.

\subsection{Energy-efficient designs}

With the aid of PKPM software, the limit HTC of each masonry material was calculated statically according to the local climate, shape coefficient and thermal inertia indices. Next, the thermal properties of building envelope with each masonry material was computed dynamically through comparative assessment and comprehensive weighting. The optimal designs for exterior walls made of the SPBs, the AAC blocks and the CAC blocks that ensure building energy efficiency are listed in Tables 2 4, respectively.

Table 2. Structural design for the exterior walls made of the SPBs

\begin{tabular}{|c|c|c|}
\hline & Wall structure & Thermal bridge structure \\
\hline $\begin{array}{c}\text { Exterior } \\
\text { wall }\end{array}$ & $\begin{array}{c}\text { Cement mortar }(20.0 \mathrm{~mm}) \\
\text { SPBs }(200.0 \mathrm{~mm}) \\
\text { Interface agent } \\
\text { Inorganic lightweight aggregate thermal insulation mortar, } \\
\text { type I (35.0mm) } \\
\text { Crack-resistant mortar fiberglass mesh }(5.0 \mathrm{~mm}) \\
\end{array}$ & $\begin{array}{c}\text { Cement mortar }(20.0 \mathrm{~mm}) \\
\text { Reinforced concrete }(200.0 \mathrm{~mm}) \\
\text { Interface agent } \\
\text { Inorganic lightweight aggregate thermal insulation mortar, } \\
\text { type I }(35.0 \mathrm{~mm}) \\
\text { Crack-resistant mortar fiberglass mesh }(5.0 \mathrm{~mm})\end{array}$ \\
\hline $\begin{array}{l}\text { Weighted } \\
\text { HTC }\end{array}$ & \multicolumn{2}{|c|}{$\begin{array}{c}\mathrm{K}=1.27 \mathrm{~W} /\left(\mathrm{m}^{2} \cdot \mathrm{k}\right) \text {, falling within the required interval of } 1.0 \sim 1.5 \mathrm{~W} /\left(\mathrm{m}^{2} \cdot \mathrm{K}\right) \text {; The designed annual energy consumption is } \\
24.95 \mathrm{kWh} / \mathrm{m}^{2} \text {, below that }\left(25.17 \mathrm{kWh} / \mathrm{m}^{2}\right) \text { of the reference building. }\end{array}$} \\
\hline
\end{tabular}


Table 3. Structural design for the exterior walls made of the AAC blocks

\begin{tabular}{|c|c|c|}
\hline & Wall structure & Thermal bridge structure \\
\hline $\begin{array}{l}\text { Exterior } \\
\text { wall }\end{array}$ & $\begin{array}{c}\text { Crack-resistant mortar fiberglass mesh }(5.0 \mathrm{~mm}) \\
\text { Cement mortar }(10.0 \mathrm{~mm}) \\
\text { Interface agent } \\
\text { AAC blocks }(\mathrm{B} 07)(200.0 \mathrm{~mm}) \\
\text { Interface agent } \\
\text { Inorganic lightweight aggregate thermal insulation mortar, } \\
\text { type I }(30.0 \mathrm{~mm}) \\
\text { Crack-resistant mortar fiberglass mesh }(5.0 \mathrm{~mm})\end{array}$ & $\begin{array}{c}\text { Crack-resistant mortar fiberglass mesh }(5.0 \mathrm{~mm}) \\
\text { Cement mortar }(10.0 \mathrm{~mm}) \\
\text { Reinforced concrete }(200.0 \mathrm{~mm}) \\
\text { Interface agent } \\
\text { Inorganic lightweight aggregate thermal insulation mortar, } \\
\text { type I }(30.0 \mathrm{~mm}) \\
\text { Crack-resistant mortar fiberglass mesh }(5.0 \mathrm{~mm})\end{array}$ \\
\hline $\begin{array}{l}\text { Weighted } \\
\text { HTC }\end{array}$ & \multicolumn{2}{|c|}{$\begin{array}{l}\mathrm{K}=1.15 \mathrm{~W} /\left(\mathrm{m}^{2} \cdot \mathrm{k}\right) \text {, falling within the required interval of } 1.0 \sim 1.5 \mathrm{~W} /\left(\mathrm{m}^{2} \cdot \mathrm{K}\right) \text {; The designed annual energy consumption is } \\
24.84 \mathrm{kWh} / \mathrm{m}^{2} \text {, below that }\left(25.17 \mathrm{kWh} / \mathrm{m}^{2}\right) \text { of the reference building. }\end{array}$} \\
\hline
\end{tabular}

Table 4. Structural design for the exterior walls made of the CAC blocks

\begin{tabular}{|c|c|c|}
\hline & Wall structure & Thermal bridge structure \\
\hline $\begin{array}{c}\text { Exterior } \\
\text { wall }\end{array}$ & $\begin{array}{l}\text { Cement mortar }(20.0 \mathrm{~mm}) \\
\text { CAC blocks }(\mathrm{B} 07)(200.0 \mathrm{~mm}) \\
\text { Cement mortar }(30.0 \mathrm{~mm})\end{array}$ & $\begin{array}{c}\text { Cement mortar }(20.0 \mathrm{~mm}) \\
\text { Reinforced concrete }(200.0 \mathrm{~mm}) \\
\text { Interface agent } \\
\text { Inorganic lightweight aggregate thermal insulation mortar, type I }(25.0 \mathrm{~mm}) \\
\text { Crack-resistant mortar fiberglass mesh }(5.0 \mathrm{~mm})\end{array}$ \\
\hline $\begin{array}{l}\text { Weighted } \\
\text { HTC }\end{array}$ & \multicolumn{2}{|c|}{$\begin{array}{l}\mathrm{K}=1.31 \mathrm{~W} /\left(\mathrm{m}^{2} \cdot \mathrm{k}\right) \text {, falling within the required interval of } 1.0 \sim 1.5 \mathrm{~W} /\left(\mathrm{m}^{2} \cdot \mathrm{K}\right) \text {; The designed annual energy consumption is } \\
24.84 \mathrm{kWh} / \mathrm{m}^{2} \text {, below that }\left(25.17 \mathrm{kWh} / \mathrm{m}^{2}\right) \text { of the reference building. }\end{array}$} \\
\hline
\end{tabular}

As shown in Tables 2 4, the exterior walls made of the SPBs, the AAC blocks and the CAC blocks, following the optimal structural designs, all reached the required energy efficiency for buildings. The exterior walls of the CAC blocks, which contain no exterior insulation layer or crack-resistant layer, were constructed with the fewest steps. The simple construction method saves materials and manpower, shortens the construction period and improves construction efficiency.

\subsection{Cost analysis}

The unit work costs (e.g. divisional work and item work costs, additional costs, regulatory costs and taxes) of exterior walls made of the SPBs, the AAC blocks and the CAC blocks were computed by GBQ cost analysis software [20]. The computation was carried out by the comprehensive unit price method according to the bid price model of construction and installation projects and the items listed in the Composition of Cost Items in Construction and Installation Projects (Jian/Biao (2013) No. 44). The labor and material costs were converted based on the quota of 2013 Budget of Zhejiang province and the market prices of that province in December, 2018. The computation results are listed in Tables 5 7.

Table 5. Unit work costs of the exterior walls made of the SPBs

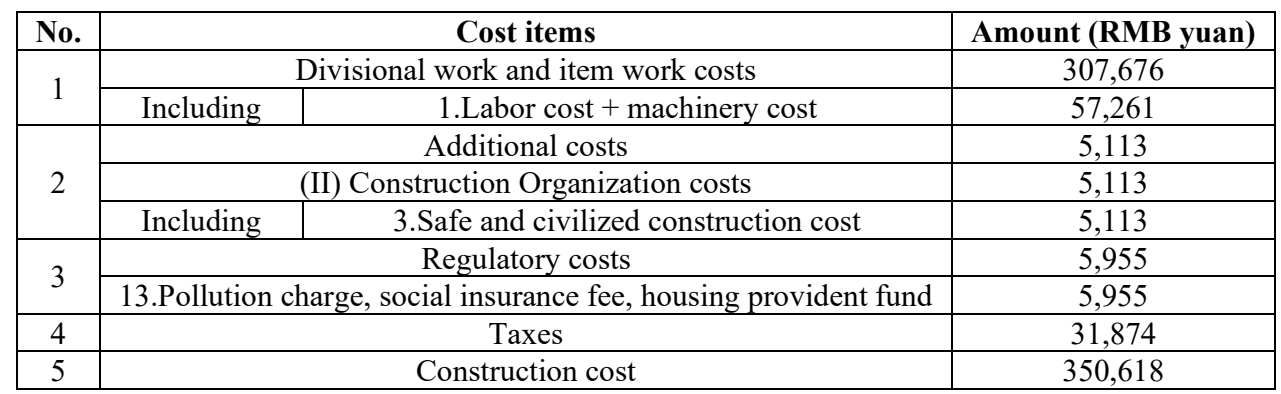

Table 6. Unit work costs of the exterior walls made of the AAC blocks

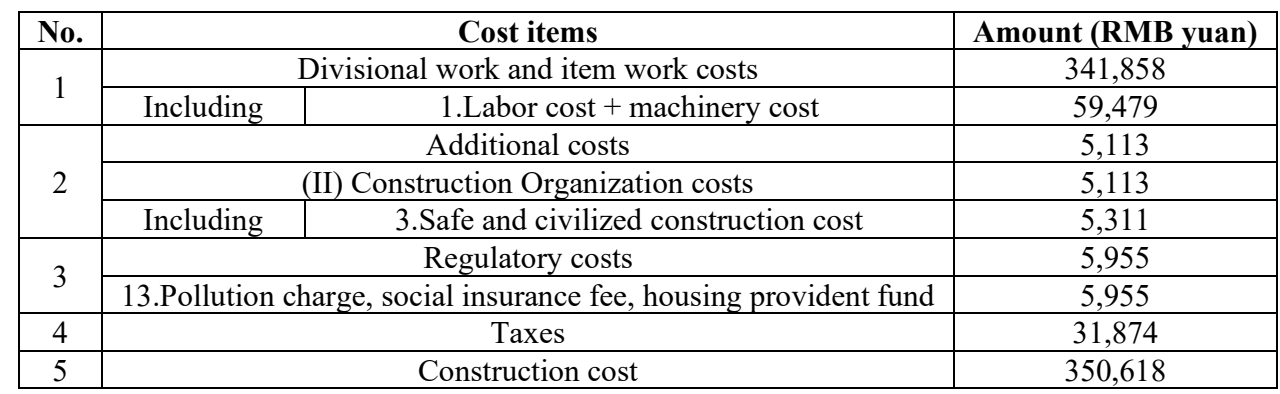


Table 7. Unit work costs of the exterior walls made of the CAC blocks

\begin{tabular}{|c|c|c|c|}
\hline No. & & & Amount (RMB yuan) \\
\hline \multirow{2}{*}{1} & \multicolumn{2}{|c|}{ Divisional work and item work costs } & 297,876 \\
\hline & Including & 1.Labor cost + machinery cost & 42,735 \\
\hline \multirow{3}{*}{2} & & Additional costs & 5,113 \\
\hline & \multicolumn{2}{|c|}{ (II) Construction Organization costs } & 5,113 \\
\hline & Including & 3. Safe and civilized construction cost & 3,816 \\
\hline \multirow{2}{*}{3} & & Regulatory costs & 5,955 \\
\hline & 13.Pollution & social insurance fee, housing provident fund & 5,955 \\
\hline 4 & & Taxes & 31,874 \\
\hline 5 & & Construction cost & 350,618 \\
\hline
\end{tabular}

The comparison between Tables 5 7 shows that the exterior walls of CAC blocks incurred much less construction cost than those of the SPBs and the AAC blocks. In terms of unit work cost, the exterior walls of CAC blocks costed RMB 13,900yuan fewer than those of the SPBs, and RMB 51,900-yuan fewer than those of the AAC blocks. In terms of the cost per unit area, the exterior walls of CAC blocks costed RMB 5.91 yuan $/ \mathrm{m}^{2}$ fewer than those of the SPBs, and RMB 22.12 yuan $/ \mathrm{m}^{2}$ fewer than those of the AAC blocks.

\section{CONCLUSIONS}

Taking a residential building in Jinhua, China as example, this paper carries out technical and economic analysis on the exterior walls made of the SPBs, the AAC blocks and the CAC blocks, using the energy-efficient design software PKPM and the cost analysis software GBQ. It is learned that the CAC blocks satisfy the requirements of the current national code for building energy conservation, and have excellent technical features, such as lightweight, high strength, thermal insulation, ultralow shrinkage, strong impermeability and sound insulation [21]; the exterior walls made of the CAC blocks contain two fewer layers than those of the other masonry materials, consume relatively few materials and manpower, and are easy and fast to build; the exterior walls made of the CAC blocks have a per unit area cost of only RMB 143.36 yuan $/ \mathrm{m}^{2}, 3.96 \%$ lower than that of the exterior walls made of the SPBs and $13.37 \%$ lower than that of the exterior walls made of the AAC blocks. These results show that the application of the CAC blocks in exterior walls can save resources and reduce building energy consumption, achieve excellent technical, economic and social benefits, and should be promoted in building projects. The proposed structural design and cost analysis methods for exterior walls of energyefficient buildings provide a good reference for energyefficient design, material selection and cost analysis in other projects.

\section{REFERENCES}

[1] Xu, H.X., Wan, C.T., Zhang, X.Y. (2018). Development status and trend of building insulation and energy-saving wall. Block-Brick-Tile, Nol. 9, pp. 91-92. http://doi.org/10.3969/j.issn.1001-6945.2018.09.030

[2] Allouhi, A., Fouih, Y.E., Kousksou, T., Jamil, A., Zeraouli, Y., Mourada, Y. (2015). Energy consumption and efficiency in buildings: Current status and future trends. Journal of Cleaner Production, 109(16): 118-130. https://doi.org/10.1016/j.jclepro.2015.05.139

[3] Mirrahimi, S., Mohamed, M.F., Haw, L.C., Ibrahim,
N.L.N., Yusoff, W.F.M., Aflaki, A. (2016). The effect of building envelope on the thermal comfort and energy saving for high-rise buildings in hot-humid climate. Renewable and Sustainable Energy Reviews, 53: 15081519. https://doi.org/10.1016/j.rser.2015.09.055

[4] Yousefi, F., Gholipour, Y., Yanb, W. (2017). A study of the impact of occupant behaviors on energy performance of building envelopes using occupants' data. Energy and Buildings, 148: 182-198. https://doi.org/10.1016/j.enbuild.2017.04.085

[5] Wei, S.L. (2018). Research on new exterior wall insulation technology and energy saving building outer wall self-insulation system. Fly Ash Comprehensive Utilization, 5: 143-145, 153. https://doi.org/10.3969/j.issn.1005-8249.2018.05.036

[6] Chwieduk, D.A. (2017). Towards modern options of energy conservation in buildings. Renewable Energy, 101: 1194-1202. https://doi.org/10.1016/j.renene.2016.09.061

[7] Berardi, U. (2017). A cross-country comparison of the building energy consumptions and their trends. Resources, Conservation and Recycling, 123: 230-241. https://doi.org/10.1016/j.resconrec.2016.03.014

[8] Atam, E. (2017). Current software barriers to advanced model-based control design for energy-efficient buildings. Renewable and Sustainable Energy Reviews, 73:

1031-1040. https://doi.org/10.1016/j.rser.2017.02.015

[9] Najjar, M., Figueiredo, K., Hammad, A.W.A., Haddad, A. (2019). Integrated optimization with building information modeling and life cycle assessment for generating energy efficient buildings. Applied Energy, 250(15): https://doi.org/10.1016/j.apenergy.2019.05.101

[10] Aditya, L., Mahlia, T.M.I., Rismanchi, B., Ng, H.M., Hasan, M.H., Metselaar, H.S.C., Muraza, O., Aditiya, H.B. (2017). A review on insulation materials for energy conservation in buildings. Renewable and Sustainable Energy Reviews, 73: 1352-1365. https://doi.org/10.1016/j.rser.2017.02.034

[11] Morozov, M., Strizhak, P.A. (2016). Researches of advanced thermal insulating materials for improving the building energy efficiency. Key Engineering Materials, 683:

617-625. https://doi.org/10.4028/www.scientific.net/KEM.683.61 7

[12] Lizana, J., Chacartegui, R., Barrios-Padura, A. (2017). Advances in thermal energy storage materials and their applications towards zero energy buildings: A critical review. Applied Energy, 203(1): 219-239.

[13] Zouaoui, H., Bouaziz, J. (2017). Physical and mechanical properties improvement of a porous clay ceramic. 
Applied Clay Science, 150(15): 131-137. https://doi.org/10.1016/j.clay.2017.09.002

[14] Muhammad, R.A., Chen, B., Shah, S.F.A. (2019). Investigate the influence of expanded clay aggregate and silica fume on the properties of lightweight concrete. Construction and Building Materials, 220(30): 253-266. https://doi.org/10.1016/j.conbuildmat.2019.05.171

[15] Chaipanich, A., Chindaprasirt, P. (2015). The properties and durability of autoclaved aerated concrete masonry blocks. Eco-Efficient Masonry Bricks and Blocks, pp. 215-230. https://doi.org/10.1016/B978-1-78242-3058.00009-7

[16] Yu, H.Z. (2014). Comparison of energy-saving insulation block with other blocks. Block-Brick-Tile, 9: 58-60. https://doi.org/10.3969/j.issn.10016945.2014.09.018

[17] Riepe, F.W. (2018). An innovative application of autoclaved aerated concrete technology. Wiley Online Library, 2(4): 103-108. https://doi.org/10.1002/cepa.864
[18] Ahmad, M.R., Chen, B. (2019). Experimental research on the performance of lightweight concrete containing foam and expanded clay aggregate. Composites Part B: Engineering, $171(15)$ : https://doi.org/10.1016/j.compositesb.2019.04.025

[19] Holanda, J.N.F. (2015). The properties and durability of clay fly ash-based fired masonry bricks. Eco-Efficient Masonry Bricks and Blocks, pp. 85-101. https://doi.org/10.1016/B978-1-78242-305-8.00005-X

[20] Wu, T.L., Long, J.Y., Yu, Q. (2018). The influence of autoclaved aerated concrete block on project cost. Construction Economy, 38(8): 79-82. https://doi.org/10.14181/j.cnki.1002-851x.201808079

[21] Talang, R.P.N., Sirivithayapakorn, S. (2018). Comparing environmental burdens, economic costs and thermal resistance of different materials for exterior building walls. Journal of Cleaner Production, 197(1): 1508-1520. https://doi.org/10.1016/j.jclepro.2018.06.255 